\title{
Effect of Psycho educational Program on Psychological Stress and Quality of Life among patients with Hepatitis C Virus
}

\author{
Hend Ahmed Mostafa Hassinine,_Sayeda Ahmed Abd Ellatief, Maaly Ibrahim Elmalky and \\ Mawaheb Mahmoud Zaki \\ Psychiatric and Mental Health Nursing- Faculty of Nursing - Benha University
}

\begin{abstract}
Background: Patients with HCV face numerous emotional and psychological stressors that have a significant effect on their well beings and their quality of life. This study aimed to evaluate the effect of psycho educational program on psychological stress and quality of life among patients with Hepatitis C Virus. A quasi experimental design was utilized to achieve the aim of the study. The study was conducted in hepatic unit and medical units at Benha University Hospital, which is affiliated to the Ministry of High Education. A purposive sample of (40) patients with HCV (22 female and 18 male) was selected from the above mentioned settings. The study tools divided into three tools. Tool (I): Structured Interview Questionnaire to assess sociodemographic and clinical characteristics. Tool (II): Stress Scale and Tool (III): Quality of life scale. Results: Findings indicated that there were highly statistically significant reduction in the severity of total stress and highly statistically significant improvement in the level of total quality of life post program implementation than before. Also, there was a highly statistically significant negative correlation between total stress and total quality of life scores of studied HCV patients' pre and post program implementation. Conclusion: The psycho educational nursing program had a positive effect on the psychological stress and quality of life among studied patients with hepatitis $\mathrm{C}$ virus. The study recommended that generalization of psycho-educational program for all patients with hepatitis $\mathrm{C}$ virus in all hospitals to alleviate their psychological stress and improve their quality of life.
\end{abstract}

Key words: Hepatitis C, Psychological Stress, Quality of Life, Psycho-education.

Introduction

Hepatitis $\mathrm{C}$ is found worldwide and the most affected regions are Africa and East Asia. Depending on the country, Hepatitis C infection can be concentrated in certain populations (for example, among people who inject drugs); and/or in general populations. About $130-170$ million people globally have chronic hepatitis $\mathrm{C}$ infection with approximately 500000 people die each year from hepatitis C. Hepatitis $\mathrm{C}$ virus is a blood borne virus and the most common modes of transmission are through unsafe injection practices; inadequate sterilization of medical equipment; and the transfusion of unscreened blood and blood products (Lozano et al., 2015).

It's natural for everyone to feel stress, but people with hepatitis $\mathrm{C}$ have additional concerns as they have continuous worry about infecting others, medical tests and 
medical bills. Being diagnosed with hepatitis $\mathrm{C}$ can be especially stressful because of the uncertainty associated with its course. Uncertainty creates a feeling of helplessness and angry either at themselves or at someone else because they always pre- occupied about how they performing activities of daily living and coping with disease. This anger can lead to depression, which only leads to the burden of emotional stress. Furthermore, stress can erode the quality of life, taking the pleasure out of work and relationships and affecting not only the health but social, financial, sexual and family life of the patients is adversely affected due to the virus (Peter, 2016).

The quality of life of patients suffering from Hepatitis $\mathrm{C}$ is significantly declined. This decline is mainly due to extra hepatic effects, common symptoms and fear of this disease. The main worry among patients is whether it can be cured or not, about the side effects during treatment and normal life span after successful completion of treatment. People with hepatitis $\mathrm{C}$ report less confidence in their current health and more concern about their health in the future. It is the duty of treating physicians and their team to assess the effects of hepatitis on the quality of life of patients and counsel them properly and regularly, so that they can improve their quality of life. There has to be emotional connect between the treating team and patients which will definitely prove to be turning factor in successful completion of treatment and thus increasing quality of life needy patients who are suffering from this deadly disease (Parveen et al., 2016).

\section{Significance of the study:}

Hepatitis $\mathrm{C}$ virus (HCV) is a major cause of liver disease worldwide and a potential cause of substantial morbidity and mortality in the future (Klenerman et al., 2015).In addition, Hepatitis $\mathrm{C}$ virus (HCV) is a globally prevalent pathogen as the most recent estimates of disease burden show an increase in prevalence over the last 15 years to $2.8 \%$, equating to $>185$ million infections worldwide. While the incidence rate of $\mathrm{HCV}$ infection is apparently decreasing in the developed world, deaths from liver disease secondary to HCV infection will continue to increase over the next 20 years (Flaxman et al., 2015).

Aim of the study:

\section{This study aims to:}

Evaluate the effect of psycho educational nursing program on psychological stress and quality of life among patients with Hepatitis C Viru

\section{Research Hypothesis:}

The psycho educational nursing program will minimize psychological stress and improve quality of life than before program.

\section{Subjects and Method:}

\section{Research Design:}

A quasi experimental design (one group prelposttest) was utilized to achieve the aim of the study.

\section{Research Setting:}

The study was conducted in hepatic unit and medical units at Benha University Hospital, which is affiliated to the Ministry of high education.

\section{Research subjects:}

Based on the previous studies that examine the same outcome and found significance differences, sample size has been calculated using the following equation: $\mathrm{n}=\left(\mathrm{z}^{2} \times \mathrm{p} \times \mathrm{q}\right) / \mathrm{D}^{2}$ at power $80 \%$ and CI $95 \%$, the average sample size was (40 to 45 patients), so the sample of the study 
was purposive sample of (40) patients with Hepatitis C Virus who are hospitalized at the above mentioned settings and fulfill the following inclusion and exclusion criteria:

\section{Inclusion criteria:}

- Diagnosed as Chronic Hepatitis C.

- Both genders.

- Hospitalized patients at the age group from 18-65 years.

Accepted and willingness to participate in the study.

\section{Exclusion criteria:}

-Patients with another chronic physical disease.

-Patients who have history of psychotic symptoms.

-Patients who have history of neurological disorders.

-Patients who have visual and hearing impairment.

\section{Tools of Data Collection:}

The data was collected using the following tools:

\section{Tool (1):-Structured Interview} Questionnaire:

This tool was developed by the researcher based on pertinent literature and guidance of supervisors to elicit information about socio-demographic and clinical characteristics of patients such as age, sex, marital status, level of education, occupation, residence, onset of illness, mode of transmission of disease and number of hospital admission.

Tool (2):- Stress Scale for Patients with Hepatitis C Virus:

This scale was developed by (Jacob, 2005). It was translated into Arabic and tested for reliability and validity by (Wafa, 2015). It's used to assess psychosocial stress; it consisted of 25 items in the form of likert scale covering psychological, physiological, social and spiritual areas of stress. Positive and negative statements were included in the scale. The response alternatives were always, sometimes, rarely and never. These responses score as 1, 2, 3 and 4 for positive items and 4, 3,2 and 1 for negative items.

Tool (3): Quality of life scale for patients with Hepatitis $\mathrm{C}$ virus:

This scale was originally developed by Walker et al., (1987) to identify a way of living or the manner in which people conduct their day to day activities. It has been translated into Arabic and tested for reliability and validity by (Meligy, 2006). It consisted of 28 questions in the form of likert scale covering the emotional, social, mental and physical dimensions of life. Positive and negative statements were included in the scale. The response alternatives were Disagree, Agree, Strongly agree. These responses score as (1) Disagree, (2)Agree, (3) strongly agree for positive items and (3)Disagree, (2)Agree,(1)strongly agree for negative items. The low score indicated poor quality of life and high score indicated good quality of life.

\section{Method of the study}

Field Work:- 
The present study was being conducted in four phases:

\section{I-Preparatory Phase:-}

This phase included reviewing of relevant literature and different studies related to the topic of research, using textbooks, articles, magazines, periodicals, and internet search was done to get a clear picture of all aspects related to the research topic to design the program.

\section{-Administrative Approval:}

Before starting any step in the study, an official letter was addressed from the Dean of Faculty of Nursing / Benha University to the General Director of University Hospital at Benha City, Kaluobia Governorate requesting their co-operation and permission to conduct the study. The purpose and the nature of the study were explained to the hospital's staff to obtain their co-operation to conduct the study.

\section{-Validity and Reliability:}

Content validity of tools was carried out by a Jury of 5 experts of psychiatric mental health nursing field and medical psychiatric staff. Test re-test reliability was done, $r=0.87$ for the stress scale and 0.81 for quality of life scale.

\section{Ethical considerations:}

An oral consent was obtained from each patient (male/female) to be involved in the study after explaining the purpose and importance of the study. The subjects who agreed to participate in the study were reassured about confidentiality of the information gathered and its use only for the research purpose. As well, they were informed about their right to withdraw from the study at any time without giving a reason.

\section{-Pilot study:}

A pilot study was carried out before starting the data collection. It was conducted (4 patients). The purpose of the pilot study was to test the applicability, feasibility, clarity, objectivity of the tool. In addition, it served to estimate the approximate time required for interviewing the patients as well as to find out any problems that might interfere with data collection. These patients were excluded later from the actual study sample.

\section{Designing phase:-}

This phase aims at planning for the psycho educational nursing program through setting educational objects, preparing the psycho-educational program, designing the methodology and media and determine the total number of sessions and the duration of each session.

\section{-Development of the psycho educational program:-}

The psycho- educational nursing program was developed by the researcher. Based on the results obtained from the assessment tools and review of literature, the program content was developed by the researcher in the form of a booklet, which was revised and approved by supervisors. The psycho-educational program aimed at minimizing the psychological stress and improving quality of life among patients with Chronic Hepatitis C. This educational program has a set of specific objectives for each session and the number of program's sessions was about 10 sessions and it was implemented for 2 days/ weeks and each session take about 60-90 minutes a day. The final booklet is given for patients in the first session.

\section{II-Implementation Phase:}


The implementation of the study has gone through three phases assessment phase (pre-test), implementation phase and post assessment phase).

\section{-Data collection pre-test: (Assessment phase)}

Data collection of this study was being carried out at hepatic unit and medical units at Benha University Hospital, Kaluobia Governorate. Comfortable place was chosen for interviewing the patients. Patients, orientation was done about the purpose and content of the nursing intervention program .Each patient was interviewed individually where pre test was carried out using the decided tools for data collection. The pre-test was collected two days per week (Saturday and Tuesday at10 a.m. to 12 p.m.) Through while average of 1-4 patients were interviewed per day. Each interview lasted for 20-25 minutes, depending on the response of interview. The process of data collection took a period from 1/ April to 7/ May 2017.

\section{-Implementation of the program:}

The study hypothesized that the application of the psycho-educational program will minimize psychological stress and improve quality of life among patients with Chronic Hepatitis C. The planned psycho-educational program was developed and implemented throughout (10) session\ two days \ week. Each session lasted from 60-90 minutes. The patients were classified into five groups: each group consisted of 8 patients. The sessions with patients were carried out during ( the middle of May to the end of August 2017).The program has a general objectives and every session has its specific contents and objectives, the content of the program session focused on an overview about Hepatitis C, psychological stress that accompany Hepatitis C, different coping methods with psychological stress and quality of life for patients with Hepatitis
C. This was achieved through several teaching methods as, brain storming, lecture, group discussions, demonstration, re demonstration and intervention booklet using the following media as laptop, PowerPoint, video, and pictures. At end of each session a feedback was taken and also a time was devoted for answering any questions.

\section{IV:-Evaluation Phase (Post-test):}

This phase aims at evaluate the effect of psycho educational nursing program on psychological stress and quality of life among patients with Chronic Hepatitis C. After the conduction of psycho-educational program sessions, a post test was done by using the stress scale and quality of life scale.

\section{Statistical Design:}

Analysis of the data was carried out and the collected data were organized, coded, computerized, tabulated and analyzed using the Statistical Package for Social Science (SPSS) version 20. Data were presented using descriptive statistics in the form of frequencies and percentages for qualitative variables and mean and standard deviation for quantitative variables. Qualitative variables were compared using Chi-square test $\left(\mathbf{X}^{\mathbf{2}}\right)$. A significant level value was considered when $\mathrm{p}$ - value $<0.05$ and a highly significant level value was considered when p- value $<0.001$, while p- value of $<0.05$ indicated non-significant result.

\section{Results:}

Table (1) shows the socio-demographic characteristics of studied patients with Hepatitis $\mathrm{C}$ virus. It clarified that the mean age of the studied sample was $39.55 \pm 9.78$ years. Regarding to sex, more than half of them $(55.0 \%)$ were females and the majority of them were married $(80.0 \%)$. In accordance with their education level, more than one 
third of studied patients $(40.0 \%)$ have secondary education and more than half of them are employed $(52.0 \%)$. Regarding their residence, the majority of them are from rural areas $(62.5 \%)$.

Figure (1) Comparison between total stress level among studied HCV patients pre and post program implementation $(\mathrm{N}=40)$. This figure reveals that there is a highly statistically significant reduction of the severity of total stress post program implementation than before from $(62.5 \%$ to $20.0 \%$ ) at $\mathrm{p}$ - value $<0.001$

Figure (2) Comparison between total quality of life level among studied HCV patients pre and post program implementation $(\mathrm{N}=40)$. This table illustrates that there is decrease in the level of low quality of life from $82.50 \%$ to $20.00 \%$ post program than before program and increase in the level of high quality of life from $12.5 \%$ to $35 \%$ post program than before with a highly statistically significant difference at $\mathrm{p}$ - value $<0.001 * *$

Table (2) Relationship between sociodemographic characteristics of studied HCV and the mean score of total stress pre and post program implementation $(\mathrm{N}=40)$. This tables reveals that there is no statistically significant difference between all sociodemographic characteristics items and the mean score of total stress for studied HCV patients pre and post program implementation at $\mathrm{p}$-value $>0.05$. The higher mean score of stress are found among age group between 18-25 years old, male group, widowed group, employee group, highly educated group and those who live in rural area preprogram implementation. While the higher mean score of stress post program are among basic education group and single group.

Table (3) Relationship between sociodemographic characteristics of studied HCV patients and mean score of total quality of life pre and post program implementation $(\mathrm{N}=40)$. This table shows that there is no statistically significant difference between all socio-demographic characteristics items and total quality of life mean score for studied HCV patients pre and post program implementation at $\mathrm{p}$-value $>0.05$.The higher mean score of total quality of life are found among age group between 55-65 years old, female group, widowed group, unemployed group, illiterate group and those who live in urban areas post program implementation.

Table (4) Correlation between mean score of total stress and mean score of total quality of life of studied HCV patients pre and post program implementation $(\mathrm{N}=40)$. This table shows that, there is a highly statistically significant negative correlation between mean score of total stress and mean score of total quality of life of studied HCV patients pre and post program implementation at $\mathrm{p}$ - value $<0.001^{* *}$. This is mean when stress decrease quality of life increase. 
Table (1):-Percentage distribution of studied patients with Hepatitis $\mathrm{C}$ virus according to their socio- demographic characteristics $(\mathrm{N}=40)$.

\begin{tabular}{|c|c|c|}
\hline \multirow[b]{2}{*}{ Socio- demographic Characteristics } & \multicolumn{2}{|c|}{ Studied HCV patients } \\
\hline & $\mathbf{N}$ & $\%$ \\
\hline \multicolumn{3}{|l|}{ Age(In years) } \\
\hline $18-25$ & 4 & 10.0 \\
\hline $25->35$ & 10 & 25.0 \\
\hline $35->45$ & 16 & 40.0 \\
\hline $45->55$ & 6 & 15.0 \\
\hline $55->65$ & 4 & 10.0 \\
\hline \multicolumn{3}{|c|}{ Mean \pm SD39.55 \pm 9.78} \\
\hline \multicolumn{3}{|c|}{ Sex } \\
\hline Male & 18 & 45.0 \\
\hline Female & 22 & 55.0 \\
\hline \multicolumn{3}{|c|}{ Marital status } \\
\hline Single & 6 & 15.0 \\
\hline Married & 32 & 80.0 \\
\hline Widowed & 2 & 5.0 \\
\hline \multicolumn{3}{|c|}{ Education level } \\
\hline Illiterate & 5 & 12.5 \\
\hline Basic education & 9 & 22.5 \\
\hline Secondary & 16 & 40.0 \\
\hline University & 10 & 25.0 \\
\hline \multicolumn{3}{|c|}{ Occupation } \\
\hline Employed & 21 & 52.5 \\
\hline Unemployed & 19 & 47.5 \\
\hline \multicolumn{3}{|c|}{ Residence } \\
\hline Rural & 25 & 62.5 \\
\hline Urban & 15 & 37.5 \\
\hline
\end{tabular}

Figure (1) Comparison between total stress level among studied HCV patients pre and post program implementation $(\mathrm{N}=40)$.

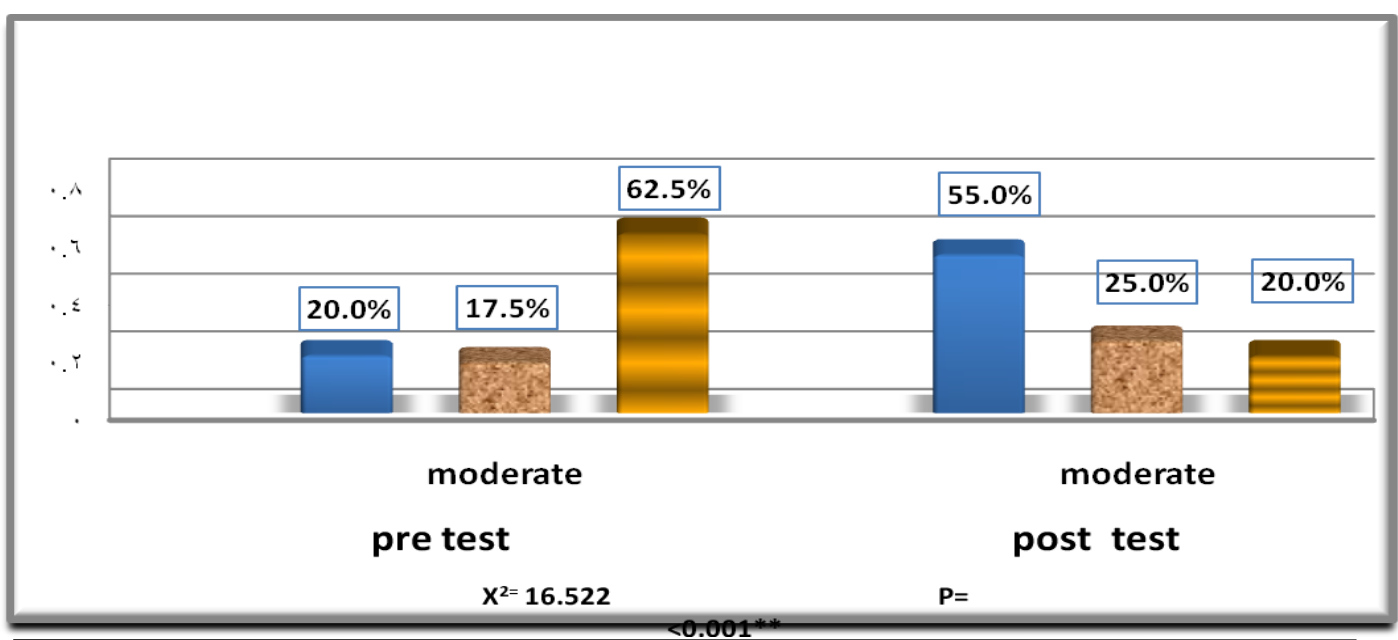


Figure (2) Comparison between total quality of life level among studied HCV patients pre and post program implementation $(\mathrm{N}=40)$.

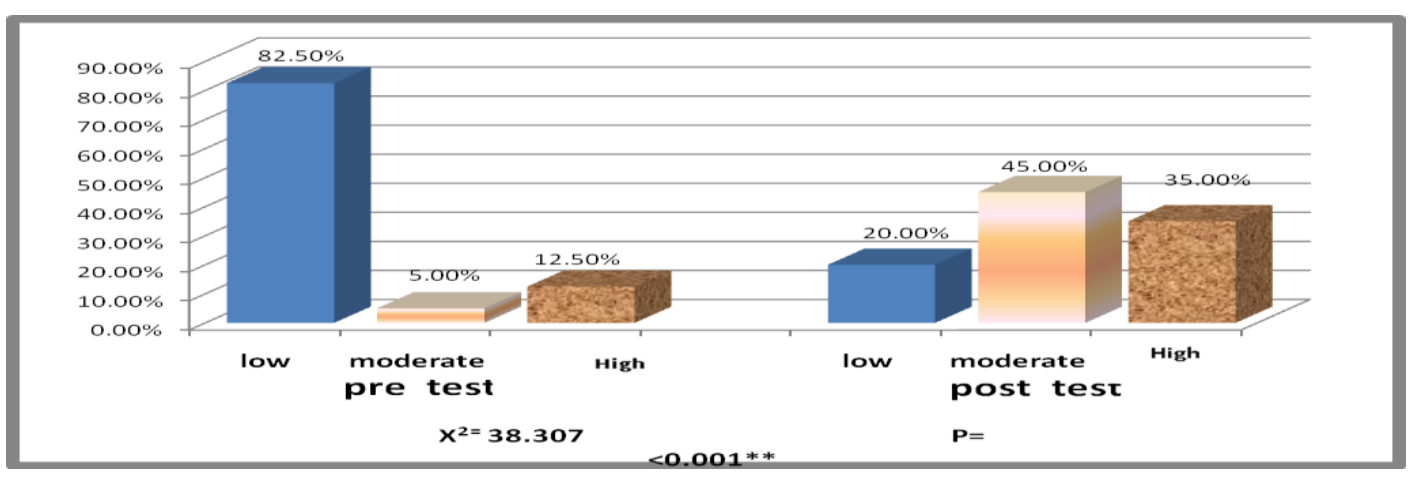

Table (2): Relationship between socio-demographic characteristics of studied HCV and the mean score of total stress pre and post program implementation $(\mathrm{N}=40)$.

\begin{tabular}{|c|c|c|c|c|c|c|c|c|c|c|c|c|c|}
\hline \multirow{2}{*}{\multicolumn{2}{|c|}{ Seciedemerphic }} & \multirow[t]{3}{*}{$\mathbf{N}$} & \multicolumn{11}{|c|}{ Totnlstres } \\
\hline & & & \multicolumn{3}{|c|}{ Fre Teat } & \multicolumn{3}{|c|}{ ANOAA ErT-tet } & \multicolumn{3}{|c|}{ Fat Tet } & \multicolumn{2}{|c|}{ ANOHA ErT-tet } \\
\hline & & & Mon & \pm & SD & & vine & P-vrhe & 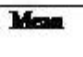 & \pm & SD & tent & P-vine \\
\hline \multirow[t]{5}{*}{$\Delta_{E}$} & 18-25 & 4 & 72500 & \pm & 11902 & \multirow[t]{5}{*}{$\mathbf{F}$} & \multirow[t]{5}{*}{0307} & \multirow[t]{5}{*}{30.05} & 6.750 & \pm & 20.839 & \multirow[t]{5}{*}{1.458} & \multirow[t]{5}{*}{30.05} \\
\hline & 25.35 & 10 & 69200 & \pm & 17.681 & & & & 54.200 & \pm & 13.710 & & \\
\hline & $35-5$ & 16 & 74375 & \pm & $15 \pm 2$ & & & & 59375 & \pm & 14.773 & & \\
\hline & $55-6$ & 6 & 71333 & \pm & 16.158 & & & & 66333 & \pm & 1697 & & \\
\hline & 5565 & 4 & 72750 & \pm & 14221 & & & & 48250 & \pm & 10.813 & & \\
\hline \multirow[t]{2}{*}{ Gender } & Nole & 18 & 7.167 & \pm & 1032 & \multirow[t]{2}{*}{$\mathbf{T}$} & \multirow[t]{2}{*}{1.631} & \multirow[t]{2}{*}{30.05} & 61.167 & \pm & 13.008 & \multirow[t]{2}{*}{0.757} & \multirow[t]{2}{*}{30.05} \\
\hline & Fonale & 22 & 69364 & \pm & 17959 & & & & 57.409 & \pm & 17.440 & & \\
\hline \multirow{3}{*}{$\begin{array}{l}\text { 16ripl } \\
\text { xtatus }\end{array}$} & stade & 6 & 72000 & \pm & 17.776 & \multirow[t]{3}{*}{$\mathbf{F}$} & \multirow[t]{3}{*}{0.759} & \multirow[t]{3}{*}{30.05} & 62.667 & \pm & 1924 & \multirow[t]{3}{*}{052} & \multirow[t]{3}{*}{30.05} \\
\hline & Mrived & 32 & 72219 & \pm & 15309 & & & & 59.031 & \pm & 15.047 & & \\
\hline & Wrilowed & 2 & 86.000 & \pm & 0.000 & & & & 49500 & \pm & 16263 & & \\
\hline \multirow{4}{*}{$\begin{array}{c}\text { Elantion } \\
\text { lesd }\end{array}$} & Illante & 5 & 66.000 & \pm & $19.4 \pm 1$ & \multirow[t]{4}{*}{$\mathbf{F}$} & \multirow[t]{4}{*}{0.632} & \multirow[t]{4}{*}{30.05} & 47.400 & \pm & 1.620 & \multirow[t]{4}{*}{2013} & \multirow[t]{4}{*}{30.05} \\
\hline & $\begin{array}{c}\text { Bacix } \\
\text { eluction }\end{array}$ & 9 & 75222 & \pm & 12194 & & & & 67.444 & \pm & 14.875 & & \\
\hline & Secondary & 16 & 71375 & \pm & 16597 & & & & 57.625 & \pm & 15.654 & & \\
\hline & Univariy & 10 & 76.600 & \pm & 14562 & & & & 59.50 & \pm & 16.019 & & \\
\hline \multirow[t]{2}{*}{ Orompatian } & Foplyzed & 21 & 75524 & \pm & 13.400 & $\mathbf{T}$ & 1.151 & 30.05 & 61.714 & \pm & 15.634 & 1.123 & 30.05 \\
\hline & Unenployed & 19 & 69947 & \pm & 17.171 & & & & 56.211 & \pm & 15299 & & \\
\hline Rectence & Barral & $\mathbf{5}$ & 74320 & \pm & 13919 & $\mathbf{T}$ & 0.764 & 30.05 & 59.900 & \pm & 14.858 & 0364 & 30.05 \\
\hline & Ubban & 15 & 70.467 & \pm & 17.768 & & & & 57933 & \pm & 17.056 & & \\
\hline
\end{tabular}

$>0.05$ No statistically significant 
Table (3): Relationship between socio-demographic characteristics of studied HCV patients and mean score of total quality of life pre and post program implementation $(\mathrm{N}=\mathbf{4 0})$.

\begin{tabular}{|c|c|c|c|c|c|c|c|c|c|c|c|c|c|}
\hline \multirow{2}{*}{\multicolumn{2}{|c|}{ Seciedemegrophic }} & \multirow[t]{3}{*}{$\mathbf{N}$} & \multicolumn{11}{|c|}{ Totnl strex } \\
\hline & & & \multicolumn{3}{|c|}{ FreText } & \multicolumn{3}{|c|}{ ANOFA ErT-teat } & \multicolumn{3}{|c|}{ Fat Iex } & \multicolumn{2}{|c|}{ ANOFA erT-tat } \\
\hline & & & Man & \pm & S1 & & tringe & P-vine & Man & \pm & S1 & $\begin{array}{l}\text { teot } \\
\text { vinhe }\end{array}$ & P-vine \\
\hline \multirow[t]{5}{*}{$\Delta E^{2}$} & 18-25 & 4 & 72500 & \pm & 11902 & \multirow[t]{5}{*}{$\mathbf{F}$} & \multirow[t]{5}{*}{0307} & \multirow[t]{5}{*}{30.05} & 68.750 & \pm & $20 \times 39$ & \multirow[t]{5}{*}{1.458} & \multirow[t]{5}{*}{30.05} \\
\hline & 2535 & 10 & 69200 & \pm & 17.681 & & & & 54.000 & \pm & 13.710 & & \\
\hline & $35-5$ & 16 & 74375 & \pm & 15.202 & & & & 59375 & \pm & 14.73 & & \\
\hline & $55-4$ & 6 & 71333 & \pm & 16.158 & & & & 66333 & \pm & 1697 & & \\
\hline & 5565 & 4 & 72750 & \pm & 14221 & & & & 42250 & \pm & 10.813 & & \\
\hline \multirow[t]{2}{*}{ Gader } & Nale & 18 & 7.167 & \pm & 1032 & \multirow[t]{2}{*}{$\mathbf{T}$} & \multirow[t]{2}{*}{1.631} & \multirow[t]{2}{*}{30.05} & 61.167 & \pm & 13.008 & \multirow[t]{2}{*}{0.757} & \multirow[t]{2}{*}{30.05} \\
\hline & Fanse & 22 & 69364 & \pm & 17959 & & & & 57.409 & \pm & 17.440 & & \\
\hline \multirow{3}{*}{$\begin{array}{l}\text { Maripl } \\
\text { thatus }\end{array}$} & Stape & 6 & 72000 & \pm & 17.776 & \multirow[t]{3}{*}{$\mathbf{F}$} & \multirow[t]{3}{*}{0.759} & \multirow[t]{3}{*}{30.05} & 62667 & \pm & 1924 & \multirow[t]{3}{*}{0528} & \multirow[t]{3}{*}{30.05} \\
\hline & Mried & 32 & 72219 & \pm & 15309 & & & & 59.031 & \pm & 15.047 & & \\
\hline & Wrined & 2 & 86.000 & \pm & 0.000 & & & & 49500 & \pm & 16263 & & \\
\hline \multirow{4}{*}{$\begin{array}{c}\text { Plaritien } \\
\text { led }\end{array}$} & ITarate & 5 & 66.000 & \pm & $19.4 \$ 1$ & \multirow[t]{4}{*}{$\mathbf{F}$} & \multirow[t]{4}{*}{0.632} & \multirow[t]{4}{*}{30.05} & 47.400 & \pm & 8.620 & \multirow[t]{4}{*}{2013} & \multirow[t]{4}{*}{30.05} \\
\hline & $\begin{array}{c}\text { Bacic } \\
\text { ederation }\end{array}$ & 9 & 752222 & \pm & 12194 & & & & 67.444 & \pm & 14.875 & & \\
\hline & Secoudary & 16 & 71375 & \pm & 16597 & & & & 57.625 & \pm & 15.654 & & \\
\hline & Univerily & 10 & 76.600 & \pm & 14562 & & & & 59.500 & \pm & 16.019 & & \\
\hline \multirow[t]{2}{*}{ Oroupation } & Finplajed & 21 & 75524 & \pm & 13.400 & $\mathbf{T}$ & 1.151 & 30.05 & 61.714 & \pm & 15.634 & 1.123 & 30.05 \\
\hline & Unemplyod & 19 & 69947 & \pm & 17.171 & & & & 56.211 & \pm & 15299 & & \\
\hline Rechence & Barrl & $\mathbf{5}$ & 74320 & \pm & 13919 & $\mathbf{T}$ & 0.764 & 30.05 & 59.200 & \pm & 14.58 & 0364 & 30.05 \\
\hline & Ubben & 15 & 70.467 & \pm & 17.768 & & & & 57933 & \pm & 17.056 & & \\
\hline
\end{tabular}

$>0.05$ No statistically significant.

Table (4): Correlation between mean score of total stress and mean score of total quality of life of studied $\mathrm{HCV}$ patients pre and post program implementation $(\mathrm{N}=$

\begin{tabular}{|c|c|c|c|c|}
\hline Correlation & \multicolumn{3}{|c|}{ O } \\
\hline \multirow{3}{*}{ Total Quality of Life } & \multicolumn{3}{|c|}{ Pre-test } & \multicolumn{2}{c|}{ Post test } \\
\cline { 2 - 6 } & \multicolumn{2}{|c|}{$\mathbf{R}$} & P-value & \multicolumn{2}{c|}{$\mathbf{R}$} & P-value \\
\cline { 2 - 6 } & -0.953 & $<0.001^{* *}$ & -0.964 & $<0.001^{* *}$ \\
\hline
\end{tabular}

\section{Discussion:}

The result of the present study revealed that less than half of studied patients with hepatitis $\mathrm{C}$ age were ranged from 35 to less than 45years and their mean age was $39.55 \pm 9.78$ years. From the researchers' point of view, this finding could be due to that the immune system progress and develop in the younger age and begin to decrease by 
age . These results were similar to studies done by Mohsen et al. (2011) \& Heneedy (2012) who found that the mean age of their studied group was $39.33 \pm 9.65$ years. However, these results are inconsistent with Ibraheim (2016) who mentioned that the majority of his studied sample was above 60 years old. and these findings are also contradicting with Younossi et al. (2012) who found that about two fifth of his studied sample were aged between 26 and 35 years old and only one fourth of the patients were aged between the ages of 46 and 55 years old.

Regarding to marital status, the present study findings reported that the majority of studied HCV patients were married. From the researchers' point of view, this finding might be due exposure to pregnancy and delivery which effect on her health and immunity and risk for infection during delivery, these results goes parallel with Alavian et al., (2010) who found that more than half of his studied sample were married. Also, these results are consistent with Ibraheim (2016) who reported that more than two thirds of his studied sample was married.

Regarding to residence, the results of the present study reported that the majority of studied sample were from rural areas. From researcher point of view this could be due to lack of heath care centers and health teaching in these areas or might be due to transmission of bad habits such as circumcision using unsterile equipment or sharing the personal equipment between all family members. These findings were similar to study done by Chemaitelly et al., (2013) who found that hepatitis $\mathrm{C}$ infection was more prevalent in rural residence in Egypt. This result comes in agreement with El-ahmady (2011) who found that nearly two thirds of his studied sample was from rural areas.

The present study findings reported that there was a highly statistically significant reduction of the severity of total stress post program implementation than before. This indicate the effectiveness of the program content and session application which was with the need and interest of the studied patients in which they taught how to cope effectively with stress through different coping methods such as deep breathing exercises, muscle relaxation technique, positive thinking, praying, exercises, reading a book and visualization.

Also, the studied patients were instructed to participate in demonstration and re-demonstration of these coping methods to reduce their feeling of stress. Furthermore, psycho educational program provide the studied patients with knowledge that help them to change their perception from negative view that hepatitis $\mathrm{C}$ is a terminal disease and there was no treatment for it to positive view that hepatitis $\mathrm{C}$ is a disease such as other chronic diseases that had possible treatment and hence recovery. These increasing patients' hope in their lives and encouraging them to perform their daily activities freely without stress. These results went parallel with the study done by Wilson (2010) who stated that psychological stress is very common among the HCV patients and there was significant reduction in severity of total stress after implementation of psycho educational program.

The findings of the current study highlighted that there was a highly statistically significant improvement in the level of total quality of life post program implementation than before. These results went parallel with the study done by Porter (2015) who reported that psycho-educational intervention program had an improving effect on quality of life of patients with hepatitis C. Also, these results were supported by the study of Sharif et al., (2011) who found that psycho-education is an important tool in improving quality of life for $\mathrm{HCV}$ patients. From the researcher point of view, these might be due to the implementation of the psycho-educational program sessions, in 
which the studied patients were taught and gained knowledge about healthy diet that was suitable to their conditions, importance of practicing exercise, cessation of smoking, importance of having friends and social network to provide them with psychological support during the moment of crisis and importance of personal hygiene. All these things help HCV patients to improve their quality of life. So psycho educational program is considered an important and essential part of the comprehensive treatment plan that mustn't be neglected and should be applied in all hospitals for patients with hepatitis $\mathrm{C}$ as it provides not only the patients but also, their families with full information about the disease and all aspects of treatment in order to improve their conditions and hence improving their quality of life.

Concerning relationship between the studied HCV patients' total mean score of stress and their socio-demographic characteristics pre and post program implementation, the current study results demonstrated that there was no statistically significant difference between patients' total mean score of stress and socio-demographic characteristics of those patients pre and post program implementation. These findings went in agreement with Malekzadeh et al.,(2013) who found no-significant relationship between $\mathrm{HCV}$ patients' total stress and their socio-demographic characteristics However, these results were contradicting with Wilson (2010) who stated that there was significant relationship between HCV patients' total stress and their age and their admission to hospital. This might be due to sample size difference and culture difference.

Regarding relationship between the studied HCV patients' total quality of life and their socio-demographic characteristics pre and post program implementation, the findings of the current study highlighted that there was no statistically significant difference between patients' total quality of life and socio-demographic characteristics of those patients' pre and post program implementation. These findings are consistent with Tawfik (2011) who reported that no significant relationship between HCV patients' quality of life and their sociodemographic characteristics and their clinical data.

As for correlation between mean score of total stress and mean score of total quality of life of studied HCV patients pre and post program implementation, the current study results revealed that there was a highly statistically significant negative correlation between mean score of total stress and mean score of total quality of life of studied HCV patients pre and post program implementation. This indicated that when stress decrease quality of life increase. This could be justified by hepatitis $\mathrm{C}$ virus produce chronic stress that preventing the patients from enjoying their normal life, performing daily activities, maintaining their interpersonal relationships and maintain selfconfidence and patience which ultimately reflect on their quality of life as it is not only the health but social, financial, sexual and family life of the patients is adversely affected due to the virus. In addition, People with hepatitis $\mathrm{C}$ report less confidence in their current health and more concern about their health in the future.

So, when increasing patients' knowledge about the disease, improving their insight about modern treatment and recovery, and encouraging compliance to medications through session of psycho educational program ,their feeling of stress decrease and hence their quality of life increase. Finally, it can be said that, the psycho-educational program in the current study has made a positive contribution in reducing psychological stress and enhancing quality of life among patients with hepatitis $\mathrm{C}$ virus. The results of this study were consistent with 
the study hypothesis that the psycho educational nursing program will minimize psychological stress and improve quality of life than before program

\section{Conclusion:}

There was a highly statistically significant correlation between total stress score and total quality of life score of the studied patient's pre / post program implementation. This concluded that the psycho educational nursing program had a positive effect on the psychological stress and quality of life among studied patients with hepatitis $\mathrm{C}$ virus which lead to acceptance of the study hypothesis that psycho-educational nursing intervention program is the key element for reducing psychological stress and improving the quality of life among studied patients with hepatitis $\mathrm{C}$ virus.

\section{Recommendations:}

Based on the findings and conclusion of this study, the following recommendations are suggested:

* Generalization of psychoeducational program for all patients with hepatitis $\mathrm{C}$ virus in all hospitals to alleviate their psychological stress and improve their quality of life.

- Stress management strategies should be thought for all patients with hepatitis $\mathrm{C}$ virus to relieve their psychological problems and enhance their coping abilities.

Psychological nursing intervention for patients with hepatitis $\mathrm{C}$ should be integrate as a part of nursing curriculum

* Community training programs should be conducted to improve people's knowledge about hepatitis $\mathrm{C}$, modes of transmission, how to prevent its transmission and prevent stigmatization for people with hepatitis $\mathrm{C}$.

\section{References:}

Alavian, S.A., Kabir, A.,\&Hajarizadeh, B.(2010). Preliminary Report of Interferon Alfha $2 b$ in Combination with Ribivirin for 48 Weeks for Treatment of Iranian Patients with Chronic Hepatitis C: AquasiExperimental Study. Shiraz E-Medical Journal, 7 (1):1-20.

Chemaitelly, H., Laith, J., Abu-raddad, F., \&Miller, D.(2013). Anapparent Lack of Epidemiologic Association between Hepatitis C Virus Knowledge and The Prevalence of Hepatitis C Infection in National Survey In Egypt, Available At:

Http://Journals.plos.org/plosone/article? $\underline{\mathrm{Id}=10.1371 / \text { Journal.Pone.0069803 . }}$

El-ahmady, A. (2011). Home Health Care Program for Patients with Hepatitis C Virus and Their Family Members in Kalyubia Governorate,Thesis of Doctorate Degree, Faculty of Nursing, Benha University.Pp.80-90.

Flaxman,A., Brown, A., Oliver, G., Messina,J., Humphreys, I., \&Barnes, E.(2015).Global Distribution and Prevalence of Hepatitis C Virus Genotypes"Hepatology; 61(1): 77-87. doi: $\underline{10.1002 / h e p .27259}$.

Heneedy, W. (2012). Study The Effect of Nursing Intervention on Physical Responses and Compliance among Patients with Liver Diseases at National Liver Institute and Menoufyia university Hospital. Un Published Doctoral Thesis. Faculty Of Nursing; Menoufyia University. Pp:70-80.

Ibraheim, E.N. (2016). Correlation Between Level of Liver Enzymes and 
Psychological distress among Patients with Hepatitis C Virus . Un Published Master Thesis, Faculty Of Nursing, Benha University, Egypt.

Jacob, V. (2005). Effectiveness of guided imagery in reduction of stress among patients with chronic illness in a selected hospital in mangalore.

Klenerman ,P.,Webster,P., \& Dusheiko, G.(2015). "Hepatitis C". The Lancet, Vol. (385), No. (9973), p: 1124-1135.

Lozano, R., Naghavi, M., Foreman, K., Lim, S., Shibuya, K., Aboyans, V., Abraham, J. \& et al. (2015). Global and regional mortality from 235 causes of death for 20 age groups in 1990 and 2015: a systematic analysis for the Global Burden of Disease Study 2015. The Lancet; 380:2095-2128.

Malekzadeh, R., Poustchi, H., \& Modabbernia, A.(2013). Neuropsychiatric and Psychosocial Issues of Patients With Hepatitis C Infection: A Selective Literature Review. Hepat Mon. 13(1): 8340. Kowsar Corp.

Meligy, L.E.(2006). "Quality of life in patients with Chronic Hepatitis $\mathrm{C}$ and its relation to depression", Master thesis, Faculty of Nursing. Elmonoufia University. p:125 .

Mohsen, M., Fareed, E., El-Sheikh, A., \&Abbas, M. (2011). Effect of Nursing Management Protocol on Selected Side Effects of Interferone and Ribavirin among Hepatitis $\mathrm{C}$ patients. Journal of American science;7(6):54-63.

Parveen,m., Naveen,m., , Vani ,m., Ajay c., Ishita ,s., Abhishek, C., and Parul ,c.(2016). Impact of Hepatitis C on Quality of Life; Advanced Research in Gastroenterology \& Hepatology1 (4): ARGH.MS.ID.555569.

Peter, M.A.(2016). Hepatitis C and Stress, Hepatitis C Health Library; Lime Health. Available at:https://consumer.healthday.com/ency clopedia/hepatitis-c-23/hepatitis-news373/hepatitis-c-and-stress-645268.html.

Porter, 1. (2015). Hepatitis C And Quality Of Life . A vailable at:

Rosen, H.R. (2014). Clinical practice. Chronic hepatitis C infection. N Engl J Med.; 364(25) pp: 2429-38

Sharif,F., Sadrollah,M., Hamid-Reza,T., \&Sakineh,G., (2011). Effects of psycho-educational intervention on health-related quality of life (QOL) of patients with chronic liver disease referring to Shiraz University of Medical Sciences.

Tawfik, E.H. (2011). Impact of an educational program on Health Related Quality of Life among virus hepatitis C patients. Alexandria University. High Institute of public health.Adv Res Gastroentero Hepatol 1(4): ARGH.MS.ID.555569 .

Wafa, F.M.(2015)."Effect of guided imagery on reducing psychological stress among patients with chronic renal failure",PHD thesis, Faculty of Nursing, Benha University.

Walker, S.N., Sechrist, K.R. \& Pender, N.J.(1987).The health promoting lifestyle profile: development and psychometric characteristics, Nursing research; 36 (2):76-81.

Wilson, M.P. (2010). Hepatitis C and depressive symptoms: psychological and social factors matter more than liver injury. Vol 40,No(2):pp 199-215.

Younossi, Z., Kallman, J., \&Kincaid, John. (2012). The effects of HCV Infection and Management on Health Related Quality of Life , Hepatology, Vol.45,No.3, 806-816. 
Effect of Psycho educational Program on Psychological Stress and Quality of Life among patients with Hepatitis C Virus 